\title{
Insertion reactions of phenyl isocyanate into hafnium nitrogen bonds: synthesis and reactivity of hafnium complexes bearing substituted pyrrolyl ligands
}

\author{
Kun-Chun Hsieh ${ }^{\text {a }}$, Wen-Yi Lee ${ }^{\text {a }}$, Chun-Liang Lai ${ }^{\text {a }}$, Ching-Han Hu ${ }^{\text {a }}$, Hon Man Lee ${ }^{\text {a }}$, \\ Jui-Hsien Huang ${ }^{a, *}$, Shie-Ming Peng ${ }^{b}$, Gene-Hsing Lee ${ }^{b}$ \\ ${ }^{a}$ Department of Chemistry, National Changhua University of Education, Changhua 500, Taiwan \\ ${ }^{\mathrm{b}}$ Department of Chemistry, National Taiwan University, Taipei 100, Taiwan
}

Received 26 March 2004; accepted 27 July 2004

Available online 27 August 2004

\begin{abstract}
A bis(diethylamido)hafnium compound $\left[\mathrm{C}_{4} \mathrm{H}_{3} \mathrm{~N}\left(\mathrm{CH}_{2} \mathrm{NMe}_{2}\right)-2\right]_{2} \mathrm{Hf}\left(\mathrm{NEt}_{2}\right)_{2}$ (1) has been prepared in $79 \%$ yield by reacting $\mathrm{Hf}\left(\mathrm{NEt}_{2}\right)_{4}$ with 2 equiv. of $\left[\mathrm{C}_{4} \mathrm{H}_{3} \mathrm{NH}\left(\mathrm{CH}_{2} \mathrm{NMe}_{2}\right)-2\right]$ in heptane via deamination. Reacting compound 1 with 2 equiv. of phenyl isocyanate at room temperature in diethyl ether results in the $\mathrm{PhNCO}$ being inserted seletively into hafnium- $\mathrm{NEt}_{2}$ bonds to generate $\left[\mathrm{C}_{4} \mathrm{H}_{3} \mathrm{~N}\left(\mathrm{CH}_{2} \mathrm{NMe}_{2}\right)-2\right]_{2} \mathrm{Hf}\left[\mathrm{PhNC}\left(\mathrm{NEt}_{2}\right)\right]_{2}(2)$ in $56 \%$ yield. Similarly, while reacting 1 with 2 equiv. of phenyl isocyanate for a week in toluene produces a mixture of 2 and $\left[\mathrm{C}_{4} \mathrm{H}_{3} \mathrm{~N}\left(\mathrm{CH}_{2} \mathrm{NMe}_{2}\right)-2\right] \mathrm{Hf}\left[\mathrm{PhNC}\left(\mathrm{NEt}_{2}\right) \mathrm{O}\right]_{3}(3)$. For comparison, reacting $\mathrm{Hf}\left(\mathrm{NEt}_{2}\right)_{4}$ with 4 equiv. of $\mathrm{PhNCO}$ in a toluene solution at room temperature results in the PhNCO inserted into Hf-N bonds, and forms a tetrakisureato hafnium compound $\mathrm{Hf}\left[\mathrm{PhNC}\left(\mathrm{NEt}_{2}\right) \mathrm{O}\right]_{4}(\mathbf{4})$ in $88 \%$ yield. A theoretical calculation found that the unpaired electrons of the ureato fragments of 2 are resonance delocalized between the $\mathrm{C}-\mathrm{O}, \mathrm{C}-\mathrm{NPh}$, and $\mathrm{C}-\mathrm{NEt} \mathrm{t}_{2}$ bonds, which are all partially doubly bonded.
\end{abstract}

(c) 2004 Elsevier B.V. All rights reserved.

Keywords: Phenyl isocyanate; Insertion hafnium; Pyrrolyl

\section{Introduction}

Organic isocyanates are useful compounds in organic synthesis because they are easily accessible and highly active toward unsaturated substrates [1]. In addition, isocyanate compounds are widely used in polymerization chemistry for producing polyurethane [2]. Some of the organic reactions of isocyanates are catalyzed by transition metal complexes [3-7] and the reactions of organic isocyanates with transition metals have been studied extensively. An excellent review by Braunstein

\footnotetext{
* Corresponding author. Tel: +886 4723 2105x3531; fax: +886 4 7211190.

E-mail address: juihuang@cc.ncue.edu.tw (J.-H. Huang).
}

and Nobel [8] described the transition-metal-mediated reactions of organic isocyanates, which covered a broad range of metal complexes. Insertion reactions of isocyanates into metal carbon or metal nitrogen bonds have been known [9-12]; however, the insertion reactions of isocyanates into early transition metal-nitrogen bonds still remain undeveloped [13-19]. Examples showed by Lappert and coworkers [20] were those $\mathrm{M}\left(\mathrm{NMe}_{2}\right)_{4}$ $(\mathrm{M}=\mathrm{Ti}, \mathrm{Zr}, \mathrm{Hf})$ react exothermically with excess of phenyl isocyanates to give $\mathrm{M}\left[\mathrm{NPhC}(\mathrm{O}) \mathrm{NMe}_{2}\right]_{4}$. However, no crystal structures were presented.

To better understand the reactivity of isocyanates toward early transition metal nitrogen bonds, here we report the synthesis and characterization of hafnium amide complexes and their reactivity toward isocyanates. 


\section{Results and discussion}

\subsection{Synthesis and characterization}

A bis(diethylamido)hafnium compound $\left[\mathrm{C}_{4} \mathrm{H}_{3} \mathrm{~N}\left(\mathrm{CH}_{2}\right.\right.$ $\left.\left.\mathrm{NMe}_{2}\right)-2\right]_{2} \mathrm{Hf}\left(\mathrm{NEt}_{2}\right)_{2}$ (1) has been prepared in $79 \%$ yield by a deamination reaction between $\mathrm{Hf}\left(\mathrm{NEt}_{2}\right)_{4}$ and 2 equiv. of $\left[\mathrm{C}_{4} \mathrm{H}_{3} \mathrm{NH}\left(\mathrm{CH}_{2} \mathrm{NMe}_{2}\right)\right.$-2] in heptane (Scheme 1). Compound $\mathbf{1}$ is highly air- and moisture sensitive, which readily decomposes upon exposure to the atmosphere. The ${ }^{1} \mathrm{H}$ and ${ }^{13} \mathrm{C}$ NMR spectra of 1 exhibit a symmetrical geometry with only one set of signals for the substituted pyrrolyl and diethylamido ligands being observed.

Reactions of compound 1 with $\mathrm{CO}_{2}$ and $\mathrm{CS}_{2}$ do not result in isolable insertion products, but rather afford the regeneration of substituted pyrrolyl ligands and un-identified products. In contrast, reaction of $\mathbf{1}$ with 2 equiv. of phenyl isocyanate at room temperature in diethyl ether for $30 \mathrm{~min}$ results in the $\mathrm{PhNCO}$ being inserted selectively into $\mathrm{Hf}-\mathrm{NEt}_{2}$ bonds to generate $\left[\mathrm{C}_{4} \mathrm{H}_{3} \mathrm{~N}\left(\mathrm{CH}_{2} \mathrm{NMe}_{2}\right)-2\right]_{2} \mathrm{Hf}\left[\mathrm{PhNC}\left(\mathrm{NEt}_{2}\right) \mathrm{O}\right]_{2}$ (2) in $56 \%$ yield. The ${ }^{13} \mathrm{C}$ NMR spectrum of 2 revealed a resonance at $\delta 165.9$, which is assignable to the quaternary carbons of ureato $\mathrm{PhNC}\left(\mathrm{NEt}_{2}\right) \mathrm{O}$ fragments. The ${ }^{1} \mathrm{H}$ NMR spectrum of 2 obtained from a $300 \mathrm{MHz}$ NMR spectrometer contains sharp resonances at $\delta 6.59$ and 6.45 attributable to the pyrrolyl fragments of the bidentate ligands. However, the dimethylamino fragments of the bidentate ligands $(\delta 2.18)$ as well as the diethylamino fragments $(\delta$ 2.78 and 0.73 ) exhibit broad signals. The signal-broadening can probably be attributed to the fluxionality of the ureato $\mathrm{PhNC}\left(\mathrm{NEt}_{2}\right) \mathrm{O}$ fragments of $\mathbf{2}$, which bind to its metal center in various modes, as shown in Scheme 2. The broad signals can be resolved in higher field NMR spectrometer. When a $600 \mathrm{MHz}$ NMR spectrometer was used, the ${ }^{1} \mathrm{H}$ NMR spectra of $\mathbf{2}$ exhibit two peaks for the dimethylamino groups and multiple resonances for the diethyl amino fragments. A comparison of the ${ }^{1} \mathrm{H}$ NMR spectra of 2 obtained from 300 and $600 \mathrm{MHz}$ NMR spectrometers was shown in Fig. 1.

Prolong stirring of 1 with 2 equiv. of $\mathrm{PhNCO}$ in toluene at room temperature for 6 days, a mixture of compounds 2 and $\left[\mathrm{C}_{4} \mathrm{H}_{3} \mathrm{~N}\left(\mathrm{CH}_{2} \mathrm{NMe}_{2}\right)-2\right] \mathrm{Hf}\left[\mathrm{PhNC}\left(\mathrm{NEt}_{2}\right)\right.$ $\mathrm{O}_{3}$ (3) can be obtained according to the ${ }^{1} \mathrm{H}$ NMR spectra. Pure compound 3 can be obtained in 14\% yield after removing volatiles and repeating recrystallization of the mixture from a diethyl ether solution. The ${ }^{13} \mathrm{C} N \mathrm{NMR}$ spectrum of 3 revealed two resonances at $\delta 166.2$ and 167.0, which are assignable to the quaternary carbons of ureato $\mathrm{PhNC}\left(\mathrm{NEt}_{2}\right) \mathrm{O}$ fragments. Again, the dimethylamino fragments of the bidentate ligands $(\delta 2.67)$ as well as the diethylamino fragments $(\delta 2.27-2.73$ and 0.73 ) exhibit broad signals due to the exchanging of bonding modes as shown in Scheme 2. No reaction was observed when monitoring a $\mathrm{C}_{6} \mathrm{D}_{6}$ solution of 2 for more than $80 \mathrm{~h}$. Therefore, the formation of $\mathbf{3}$ was proposed as the results of ligand redistribution, which only occurs when excess of PhNCO is present. Indeed, when small amount of $\mathrm{PhNCO}$ was added to the a solution of compound 2 in $\mathrm{C}_{6} \mathrm{D}_{6}, 3$ was formed together with several un-identified compounds within $12 \mathrm{~h}$ at $50{ }^{\circ} \mathrm{C}$, according to the ${ }^{1} \mathrm{H}$ NMR spectra. However, the real mechanism for the ligand redistribution is still unclear. Attempts to increase the yield of compound $\mathbf{3}$ by reacting 1 with 3 equiv. of $\mathrm{PhNCO}$ in toluene result

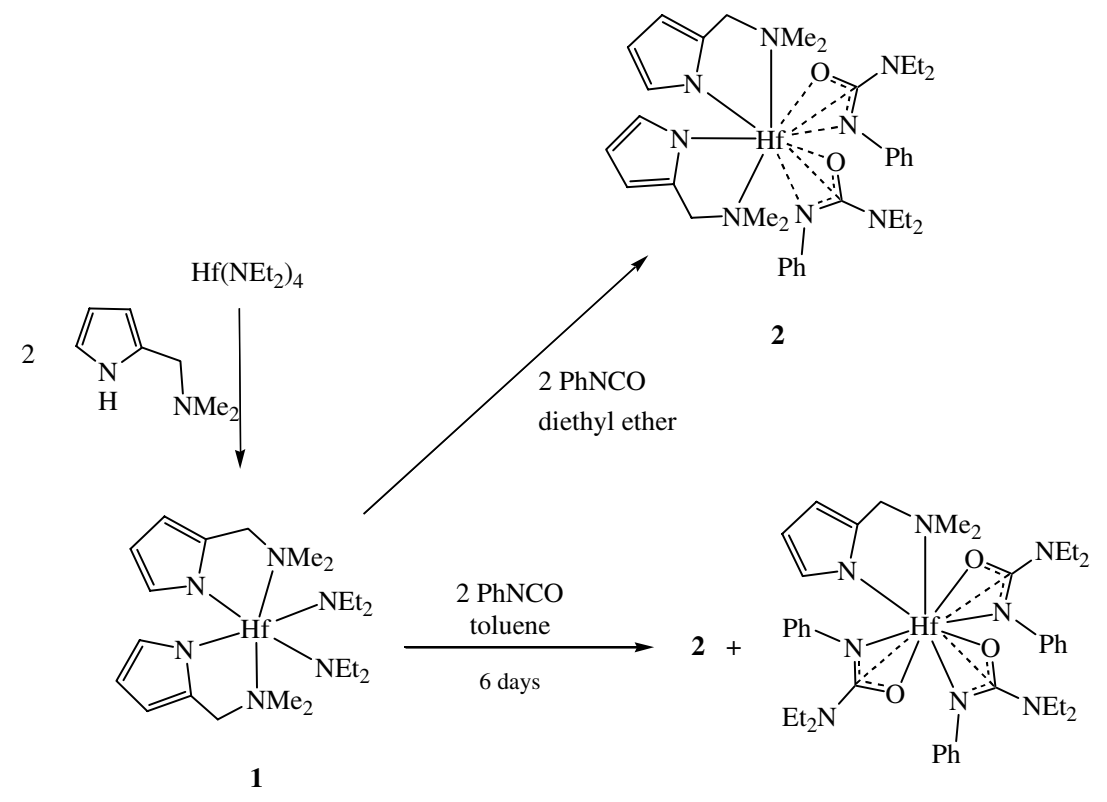

3

Scheme 1. 


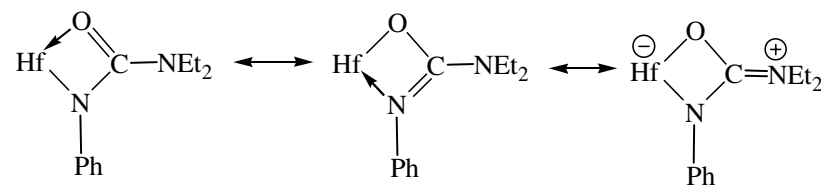

Scheme 2 .

(a)

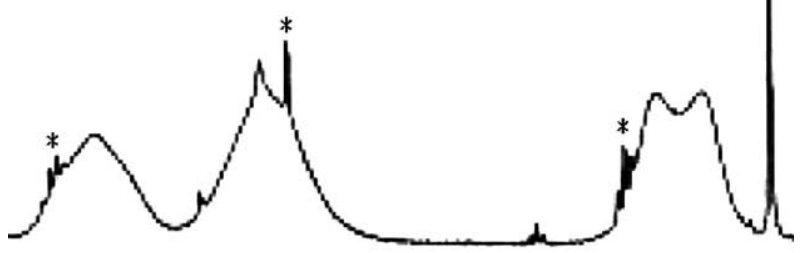

(b)
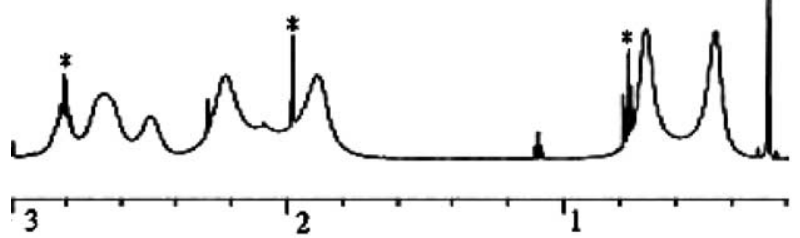

Fig. 1. The ${ }^{1} \mathrm{H}$ NMR spectra for compound 2 ranged from $\delta 0-3$, asterisk (*) represent un-identified products (a) $300 \mathrm{MHz}$ NMR spectrometer (b) $600 \mathrm{MHz}$ spectrometer.

in a mixture of $\mathbf{2}, \mathbf{3}, \mathbf{4}$, and several un-identified products. Therefore, we conclude that when 2 equiv. of $\mathrm{PhNCO}$ was added in a solution of $\mathbf{1}$, it can only insert selectively into the $\mathrm{Hf}$-amide bonds and only compounds $\mathbf{2}$ and $\mathbf{3}$ can be isolated. However, addition of PhNCO into hafnium-pyrrolyl bond may occur when excess of $\mathrm{PhNCO}$ was presented in the reaction solution (i.e., $>2$ equiv.), according to ${ }^{1} \mathrm{H}$ NMR spectra [21]. The reaction became complicate and several un-identified products besides $\mathbf{2}$ and $\mathbf{3}$ were found. All the attempts to isolate new compounds are not successful.

For comparison, reacting $\mathrm{Hf}\left(\mathrm{NEt}_{2}\right)_{4}$ with 4 equiv. of $\mathrm{PhNCO}$ in a toluene solution at room temperature results in the $\mathrm{PhNCO}$ inserted into $\mathrm{Hf}-\mathrm{N}$ bonds forming a tetrakis-ureato hafnium compound $\mathrm{Hf}[\mathrm{PhNC}(\mathrm{NE}-$ $\left.\left.\mathrm{t}_{2}\right)_{\mathrm{O}}\right]_{4}(4)$ in $88 \%$ yield (Scheme 3). A similar compound, $\mathrm{Hf}\left[\mathrm{PhNC}\left(\mathrm{NMe}_{2}\right) \mathrm{O}\right]_{4}$, has been synthesized by Lappert and coworkers [20]. The ${ }^{1} \mathrm{H}$ NMR spectrum of $\mathbf{4}$ exhibits only one set of quartet and triplet at $\delta 2.89$ and 0.71 for the ethyl protons of diethylamino groups, indicating that the four ureato $\mathrm{PhNC}\left(\mathrm{NEt}_{2}\right) \mathrm{O}$ groups are equivalent in solution at room temperature. The ${ }^{13} \mathrm{C}$ NMR

$$
\mathrm{Hf}\left(\mathrm{NEt}_{2}\right)_{4} \stackrel{4 \mathrm{PhNCO}}{\longrightarrow}
$$

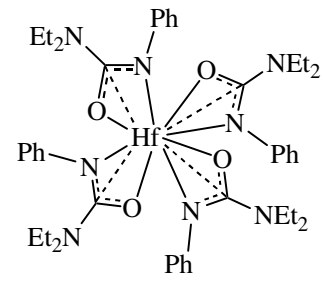

4

Scheme 3 .

spectrum of 4 exhibited a singlet at $\delta 166.6$ for the quaternary carbon of ureato $\mathrm{PhNC}\left(\mathrm{NEt}_{2}\right) \mathrm{O}$, which is similar to that of 2 .

\subsection{Molecular structures of compounds 1, 2, 3 and 4}

Crystals of 1 suitable for crystallographic studies were obtained from a toluene solution at $-20{ }^{\circ} \mathrm{C}$. Molecular structure of $\mathbf{1}$ and selected bond distances and angles are given in Fig. 2 and Table 1, respectively. The geometry of $\mathbf{1}$ is best described as a distorted octahedral with bond angles of the three axes $\mathrm{N}(1)-\mathrm{Hf}(1)$ $\mathrm{N}(6), \quad \mathrm{N}(4)-\mathrm{Hf}(1)-\mathrm{N}(5)$, and $\mathrm{N}(2)-\mathrm{Hf}(1)-\mathrm{N}(3)$ of $153.54(9)^{\circ}, \quad 162.45(8)^{\circ}$, and $165.08(8)^{\circ}$, respectively. The two substituted pyrrolyl ligands bond to the hafnium center with acute angles of $70.82(9)^{\circ}$ and $71.22(8)^{\circ}$. The two diethylamido ligands bind to the Lewis acidic hafnium atom in an asymmetrical manner and result in a short bond distance of $\mathrm{Hf}(1)-\mathrm{C}(19)(2.845(3)$ A) with small bond angle of $\mathrm{Hf}(1)-\mathrm{N}(6)-\mathrm{C}(19)$ $\left(106.20(19)^{\circ}\right)$. However, the two diethylamido ligands

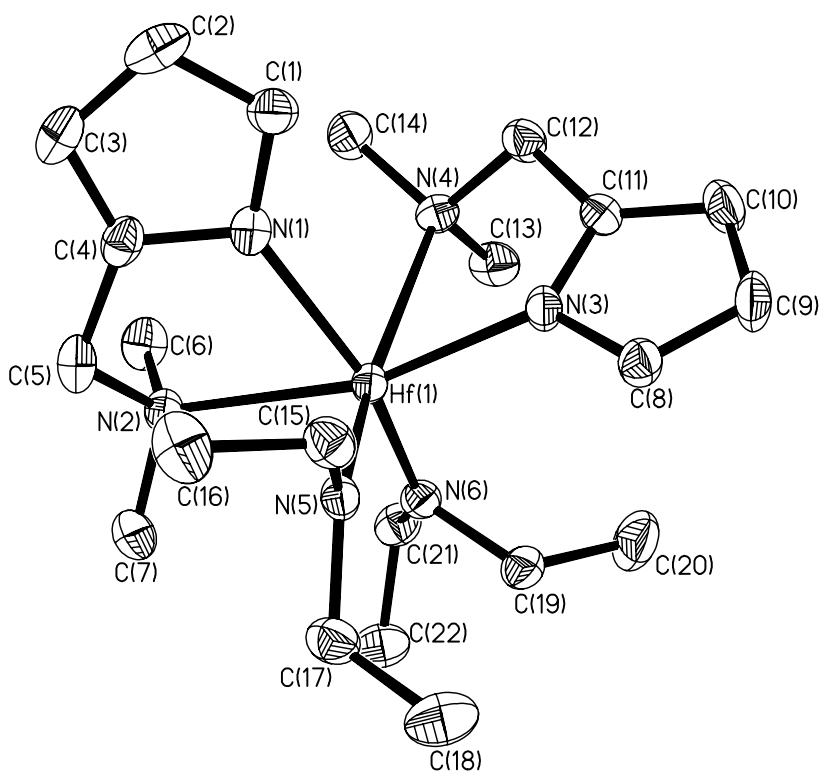

Fig. 2. The molecular structure of $\mathbf{1}$. Thermal ellipsoids were drawn at $50 \%$ probability level. 
Table 1

Selected bond distances and angles for compounds 1, 2, 3 and 4

\begin{tabular}{|c|c|c|c|c|c|}
\hline \multicolumn{6}{|l|}{1} \\
\hline $\operatorname{Hf}(1)-\mathrm{N}(1)$ & $2.207(3)$ & $\mathrm{Hf}(1)-\mathrm{N}(2)$ & $2.495(2)$ & $\operatorname{Hf}(1)-\mathrm{N}(3)$ & $2.174(2)$ \\
\hline $\mathrm{Hf}(1)-\mathrm{N}(4)$ & $2.635(2)$ & $\mathrm{Hf}(1)-\mathrm{N}(5)$ & $2.023(2)$ & $\mathrm{Hf}(1)-\mathrm{N}(6)$ & $2.046(2)$ \\
\hline $\mathrm{N}(1)-\mathrm{Hf}(1)-\mathrm{N}(2)$ & $70.82(9)$ & $\mathrm{N}(3)-\mathrm{Hf}(1)-\mathrm{N}(4)$ & $71.22(8)$ & & \\
\hline $\mathrm{N}(1)-\mathrm{Hf}(1)-\mathrm{N}(6)$ & $153.54(9)$ & $\mathrm{N}(2)-\mathrm{Hf}(1)-\mathrm{N}(3)$ & $165.08(8)$ & & \\
\hline $\mathrm{N}(4)-\mathrm{Hf}(1)-\mathrm{N}(5)$ & $162.45(8)$ & & & & \\
\hline \multicolumn{6}{|l|}{2} \\
\hline $\operatorname{Hf}(1)-\mathrm{N}(1)$ & $2.202(8)$ & $\mathrm{Hf}(1)-\mathrm{N}(2)$ & $2.563(9)$ & $\operatorname{Hf}(1)-\mathrm{N}(3)$ & $2.229(8)$ \\
\hline $\operatorname{Hf}(1)-\mathrm{N}(5)$ & $2.207(8)$ & $\mathrm{Hf}(1)-\mathrm{N}(6)$ & $2.552(11)$ & $\mathrm{Hf}(1)-\mathrm{N}(7)$ & $2.253(9)$ \\
\hline $\mathrm{Hf}(1)-\mathrm{O}(1)$ & $2.188(7)$ & $\mathrm{Hf}(1)-\mathrm{O}(2)$ & $2.189(7)$ & $\mathrm{Hf}(1)-\mathrm{C}(8)$ & $2.648(10)$ \\
\hline $\mathrm{Hf}(1)-\mathrm{C}(26)$ & $2.668(11)$ & $\mathrm{N}(3)-\mathrm{C}(8)$ & $1.334(12)$ & $\mathrm{C}(8)-\mathrm{O}(1)$ & $1.287(11)$ \\
\hline $\mathrm{C}(8)-\mathrm{N}(4)$ & $1.338(12)$ & $\mathrm{N}(7)-\mathrm{C}(26)$ & $1.327(12)$ & $\mathrm{C}(26)-\mathrm{O}(2)$ & $1.312(11)$ \\
\hline $\mathrm{C}(26)-\mathrm{N}(8)$ & $1.336(13)$ & & & & \\
\hline $\mathrm{N}(1)-\mathrm{Hf}(1)-\mathrm{N}(2)$ & $67.1(3)$ & $\mathrm{N}(5)-\mathrm{Hf}(1)-\mathrm{N}(6)$ & $66.6(3)$ & & \\
\hline $\mathrm{O}(1)-\mathrm{Hf}(1)-\mathrm{N}(3)$ & $59.1(3)$ & $\mathrm{O}(2)-\mathrm{Hf}(1)-\mathrm{N}(7)$ & $58.9(3)$ & & \\
\hline $\mathrm{N}(2)-\mathrm{Hf}(1)-\mathrm{C}(26)$ & $161.7(3)$ & $\mathrm{N}(6)-\mathrm{Hf}(1)-\mathrm{C}(8)$ & $165.1(3)$ & & \\
\hline $\mathrm{N}(3)-\mathrm{C}(8)-\mathrm{O}(1)$ & $112.5(9)$ & $\mathrm{N}(7)-\mathrm{C}(26)-\mathrm{O}(2)$ & $111.8(9)$ & & \\
\hline \multicolumn{6}{|l|}{3} \\
\hline $\mathrm{Hf}(1)-\mathrm{O}(3)$ & $2.181(6)$ & $\mathrm{Hf}(1)-\mathrm{O}(2)$ & $2.189(5)$ & $\mathrm{Hf}(1)-\mathrm{O}(1)$ & $2.191(6)$ \\
\hline $\operatorname{Hf}(1)-\mathrm{N}(7)$ & $2.206(6)$ & $\mathrm{Hf}(1)-\mathrm{N}(1)$ & $2.250(6)$ & $\mathrm{Hf}(1)-\mathrm{N}(5)$ & $2.251(6)$ \\
\hline $\mathrm{Hf}(1)-\mathrm{N}(3)$ & $2.260(6)$ & $\operatorname{Hf}(1)-\mathrm{N}(8)$ & $2.468(6)$ & $\operatorname{Hf}(1)-C(7)$ & $2.636(8)$ \\
\hline $\mathrm{Hf}(1)-\mathrm{C}(18)$ & $2.652(8)$ & $\mathrm{Hf}(1)-\mathrm{C}(29)$ & $2.656(9)$ & $\mathrm{N}(1)-\mathrm{C}(7)$ & $1.304(10)$ \\
\hline $\mathrm{O}(1)-\mathrm{C}(7)$ & $1.286(9)$ & $\mathrm{O}(2)-\mathrm{C}(18)$ & $1.295(9)$ & $\mathrm{N}(3)-\mathrm{C}(18)$ & $1.38(11)$ \\
\hline $\mathrm{O}(3)-\mathrm{C}(29)$ & $1.316(12)$ & $\mathrm{N}(5)-\mathrm{C}(29)$ & $1.313(11)$ & & \\
\hline $\mathrm{N}(7)-\mathrm{Hf}(1)-\mathrm{N}(8)$ & $88.1(2)$ & $\mathrm{O}(1)-\mathrm{Hf}(1)-\mathrm{N}(1)$ & $58.5(2)$ & & \\
\hline $\mathrm{O}(2)-\mathrm{Hf}(1)-\mathrm{N}(3)$ & $58.9(2)$ & $\mathrm{O}(3)-\mathrm{Hf}(1)-\mathrm{N}(5)$ & $59.1(2)$ & & \\
\hline \multicolumn{6}{|l|}{4} \\
\hline $\operatorname{Hf}(1)-\mathrm{N}(1)$ & $2.264(3)$ & $\mathrm{Hf}(1)-\mathrm{N}(3)$ & $2.251(3)$ & $\mathrm{Hf}(1)-\mathrm{N}(5)$ & $2.251(3)$ \\
\hline $\operatorname{Hf}(1)-\mathrm{N}(7)$ & $2.252(6)$ & $\mathrm{Hf}(1)-\mathrm{O}(1)$ & $2.208(4)$ & $\mathrm{Hf}(1)-\mathrm{O}(2)$ & $2.185(3)$ \\
\hline $\mathrm{Hf}(1)-\mathrm{O}(3)$ & $2.184(3)$ & $\mathrm{Hf}(1)-\mathrm{O}(4)$ & $2.189(3)$ & $\mathrm{Hf}(1)-\mathrm{C}(1)$ & $2.658(4)$ \\
\hline $\mathrm{Hf}(1)-\mathrm{C}(12)$ & $2.647(4)$ & $\mathrm{Hf}(1)-\mathrm{C}(23)$ & $2.653(4)$ & $\mathrm{Hf}(1)-\mathrm{C}(34)$ & $2.655(4)$ \\
\hline $\mathrm{O}(1)-\mathrm{C}(1)$ & $1.275(6)$ & $\mathrm{C}(1)-\mathrm{N}(2)$ & $1.361(5)$ & $\mathrm{C}(1)-\mathrm{N}(1)$ & $1.356(6)$ \\
\hline $\mathrm{O}(2)-\mathrm{C}(12)$ & $1.289(4)$ & $\mathrm{C}(12)-\mathrm{N}(4)$ & $1.349(5)$ & $\mathrm{C}(12)-\mathrm{N}(3)$ & $1.355(5)$ \\
\hline $\mathrm{O}(3)-\mathrm{C}(23)$ & $1.294(4)$ & $\mathrm{C}(23)-\mathrm{N}(6)$ & $1.347(5)$ & $\mathrm{C}(23)-\mathrm{N}(5)$ & $1.329(5)$ \\
\hline $\mathrm{O}(4)-\mathrm{C}(34)$ & $1.294(4)$ & $\mathrm{C}(34)-\mathrm{N}(8)$ & $1.346(5)$ & $\mathrm{C}(34)-\mathrm{N}(7)$ & $1.340(7)$ \\
\hline $\mathrm{O}(1)-\mathrm{Hf}(1)-\mathrm{N}(1)$ & $58.96(15)$ & $\mathrm{O}(2)-\mathrm{Hf}(1)-\mathrm{N}(3)$ & $59.55(10)$ & & \\
\hline $\mathrm{O}(3)-\mathrm{Hf}(1)-\mathrm{N}(5)$ & $59.04(10)$ & $\mathrm{O}(4)-\mathrm{Hf}(1)-\mathrm{N}(7)$ & $59.23(16)$ & & \\
\hline $\mathrm{O}(1)-\mathrm{C}(1)-\mathrm{N}(1)$ & $113.6(4)$ & $\mathrm{O}(2)-\mathrm{C}(12)-\mathrm{N}(3)$ & $112.9(3)$ & & \\
\hline $\mathrm{O}(3)-\mathrm{C}(23)-\mathrm{N}(5)$ & $112.8(3)$ & $\mathrm{O}(4)-\mathrm{C}(34)-\mathrm{N}(7)$ & $112.9(4)$ & & \\
\hline
\end{tabular}

become equivalent in solution due to their low rotation energy barriers.

Crystals of $\mathbf{2}$ were obtained from a diethyl ether solution at $-20{ }^{\circ} \mathrm{C}$. The molecular structure and selected bond distances and angles of $\mathbf{2}$ are shown in Fig. 3 and Table 1, respectively. Compound $\mathbf{2}$ can be viewed as an eight coordinated hafnium compound with the two ureato ligands are bonded to hafnium through nitrogen and oxygen atoms. Compound 2 possesses two planar ureato metallacycles, which contain obtuse $\mathrm{N}-\mathrm{C}-\mathrm{O}$ angles of $112.5(9)^{\circ}$ and $111.8(9)^{\circ}$, as well as acute $\mathrm{N}-\mathrm{Hf}-\mathrm{O}$ angles of $59.1(3)^{\circ}$ and $58.9(3)^{\circ}$. The two substituted pyrrolyl ligands bond to the hafnium center with acute angles of $67.1(3)^{\circ}$ and $66.6(3)^{\circ}$, smaller than those of compound $\mathbf{1}$, presumably due to the larger ureato ligands compressing the bond angles of the chelated substituted pyrrolyl ligands. The $\mathrm{N}-\mathrm{C}$ (ranged from $1.327(12)$ to $1.338(13) \AA$ ) and $\mathrm{C}-\mathrm{O}(1.287(11)$ to 1.312(11) $\AA$ ) bond distances of ureato fragments are both in the range of partially double bond, indicating that the $\pi$ electrons of the ureato fragments are equally delocalized in the $\mathrm{NC}(\mathrm{N}) \mathrm{O}$ core.

Crystals of 3 suitable for crystallographic studies were obtained after repeating recrystallization of a mixture of compounds $\mathbf{2}$ and $\mathbf{3}$ diethyl ether solution at $-20{ }^{\circ} \mathrm{C}$. The molecular structure and selected bond distances and angles of $\mathbf{3}$ are shown in Fig. 4 and Table 1, respectively. A disorder occurred at one of the methyl 


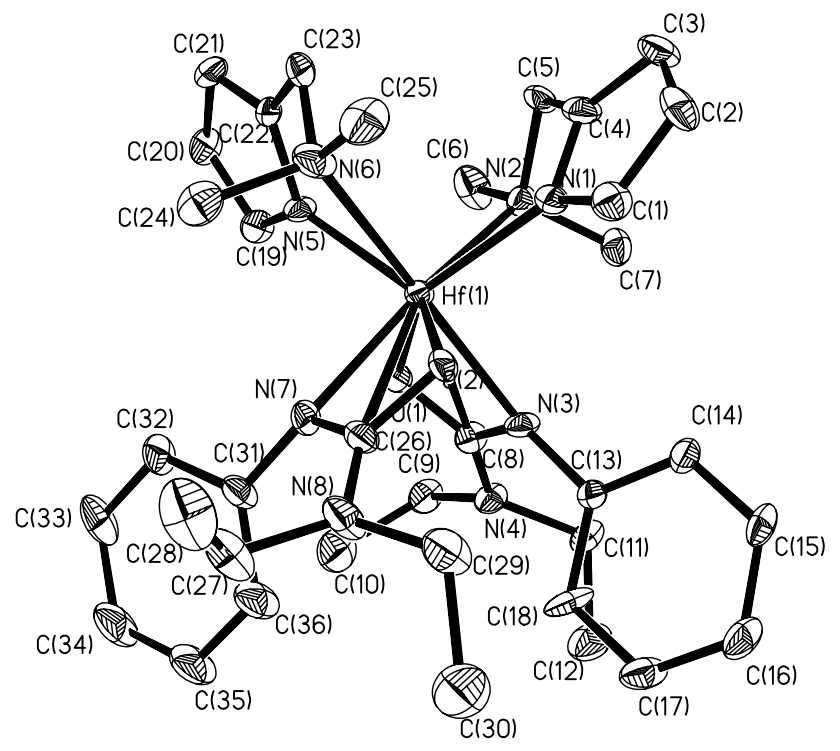

Fig. 3. The molecular structure of 2 . Thermal ellipsoids were drawn at $30 \%$ probability level.

carbon which was separated into $\mathrm{C}(33)$ and $\mathrm{C}(33)^{\prime}$ with the occupancy ratio of $60 / 40$. The bond distances and angles of $\mathbf{3}$ were similar to those of $\mathbf{2}$.

Even though $\mathrm{Hf}\left[\mathrm{PhNC}\left(\mathrm{NMe}_{2}\right) \mathrm{O}\right]_{4}$, analogous to compound 4, has been synthesized [20], no crystal structure of that has been obtained. Crystals of $\mathbf{4}$ suitable for crystallographic studies were obtained from a toluene solution at $-20^{\circ} \mathrm{C}$. The molecular structure and selected bond distances and angles of $\mathbf{4}$ are shown in Fig. 5 and Table 1, respectively. Compound $\mathbf{4}$ can also be viewed as an eight coordinate $\mathrm{MX}_{8}$ geometry [22] where ureato fragments bond to the hafnium atom through nitrogen and oxygen atoms. A simplified geometry of $\mathbf{4}$ is shown in Fig. 6 where the eight coordinated atoms are located

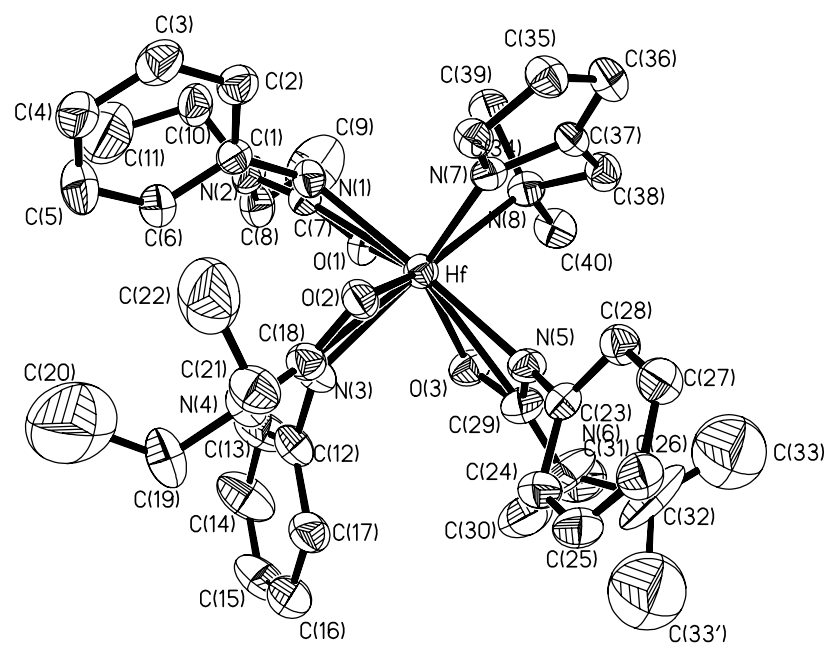

Fig. 4. The molecular structure of $\mathbf{3}$. Thermal ellipsoids were drawn at $30 \%$ probability level. $\mathrm{C}(33)$ and $\mathrm{C}(33)^{\prime}$ are disorder sites with occupancy ration of $60 / 40$.

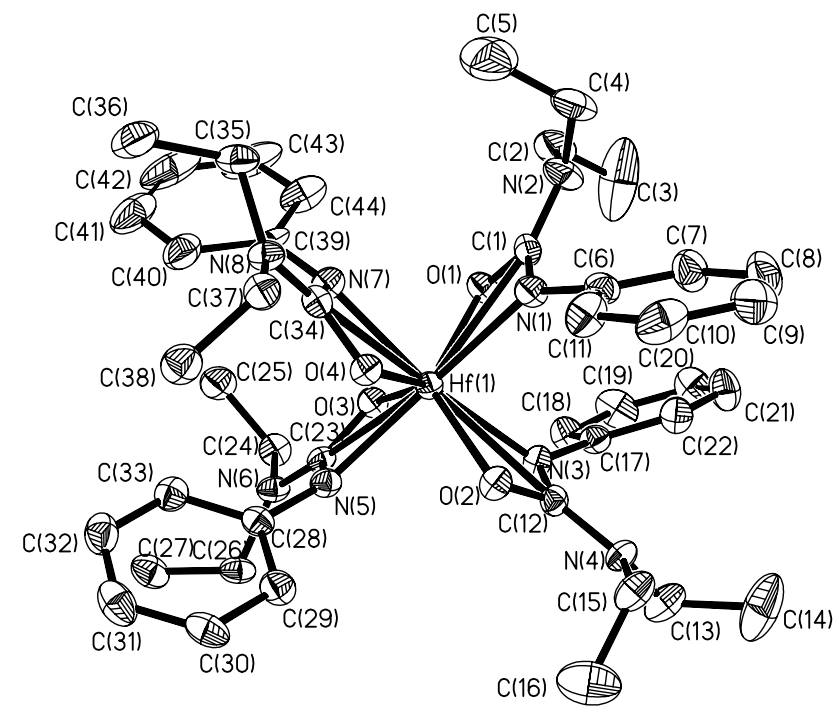

Fig. 5. The molecular structure of $\mathbf{4}$. Thermal ellipsoids were drawn at $30 \%$ probability level.
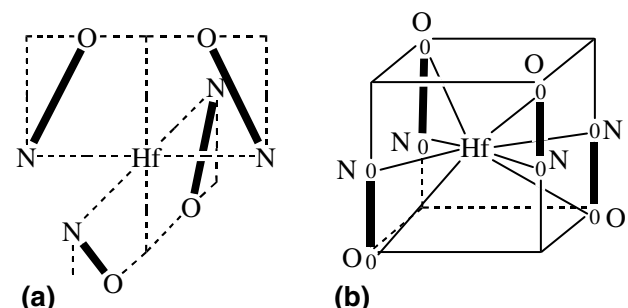

(b)

Fig. 6. $\operatorname{Hf}\left(\eta^{3}-\mathrm{NCO}\right)_{4}$ core inscribed within (a) two perpendicular rectangles and (b) an idealized cube showing the eight coordinate $\mathrm{HfN}_{4} \mathrm{O}_{4}$ unit.

on two perpendicular rectangles or in an idealized cube. The four ureato fragments coordinate to the hafnium atom forming four planar metallacycles. The bond distances and angles of $\mathbf{4}$ around the ureato metallacycles are similar to that of $\mathbf{2}$, indicating that the $\pi$ electrons of ureato fragments are evenly distributed.

\subsection{Theoretical calculation}

All calculations were performed using the hybrid B3LYP density functional theory [23,24]. For the basis sets we chose 6-31 G* for $\mathrm{H}, \mathrm{C}, \mathrm{N}, \mathrm{O}$, and LANL2DZ effective core potential plus basis functions for hafnium $[25,26]$. The reaction of $\mathbf{1}$ with $\mathrm{PhNCO}$, which yields $\mathbf{2}$, was calculated as an exothermic reaction with -65.7 $\mathrm{kcal} / \mathrm{mol}$ for the heat of emission. The calculated bond distances and angles of $\mathbf{1}$ and $\mathbf{2}$ are close to the experimental data (see supporting information). As suggested in Scheme 2, the unpaired electrons of the ureato fragments of $\mathbf{2}$ are resonance delocalized between the $\mathrm{C}-\mathrm{O}$, $\mathrm{C}-\mathrm{NPh}$, and $\mathrm{C}-\mathrm{NEt}_{2}$ bonds, which are all partially doubly bonded. 


\section{Experimental}

\subsection{General procedure}

All reactions were performed under a dry nitrogen atmosphere using standard Schlenk techniques or in a glove box. Toluene, diethyl ether, and heptane were dried by refluxing over sodium benzophenone ketyl. $\mathrm{CH}_{2} \mathrm{Cl}_{2}$ was dried over $\mathrm{P}_{2} \mathrm{O}_{5}$. All solvents were distilled and stored in solvent reservoirs which contained $4 \AA$ molecular sieves and were purged with nitrogen. $\mathrm{CDCl}_{3}$ was degassed by freeze-and-thaw method and dried over $4 \AA$ molecular sieves. ${ }^{1} \mathrm{H}$ and ${ }^{13} \mathrm{C}$ NMR spectra were recorded on a Bruker AC 200 or an Avance 300 NMR spectrometer at room temperature if not stated otherwise. Chemical shifts for ${ }^{1} \mathrm{H}$ and ${ }^{13} \mathrm{C}$ spectra were recorded in ppm relative to the residual protons and ${ }^{13} \mathrm{C}$ of $\mathrm{CDCl}_{3}(\delta 7.24,77.0)$ and $\mathrm{C}_{6} \mathrm{D}_{6}(\delta 7.16,128.0)$. Elemental analyses were performed on a Heraeus CHNOS Rapid Elemental Analyzer at the Instrument Center, NCHU. (2-dimethylaminomethyl)pyrrole was synthesized according to published literature [27,28]. $\mathrm{HfCl}_{4}$ was purchased from Aldrich Co. and used as received.

\section{2. $\left[\mathrm{C}_{4} \mathrm{H}_{3} \mathrm{~N}\left(\mathrm{CH}_{2} \mathrm{NMe}_{2}\right)-2\right]_{2} \mathrm{Hf}\left(\mathrm{NEt}_{2}\right)_{2}$ (1)}

To a $100 \mathrm{~mL}$ Schlenk flask charged with $20 \mathrm{~mL}$ heptane and $\mathrm{Hf}\left(\mathrm{NEt}_{2}\right)_{4}(3.0 \mathrm{~g}, 6.42 \mathrm{mmol})$ was added dropwise with a $\mathrm{C}_{4} \mathrm{H}_{4} \mathrm{~N}\left(\mathrm{CH}_{2} \mathrm{NMe}_{2}\right)(1.59 \mathrm{~g}, 12.8 \mathrm{mmol}) /$ heptane $(20 \mathrm{~mL})$ solution at room temperature with stirring for $12 \mathrm{~h}$. Volatiles were removed under vacuum and the resulting solids were recrystallized from a toluene solution to generate $2.89 \mathrm{~g}$ of white solids in $79 \%$ yield. ${ }^{1} \mathrm{H}$ NMR $\left(\mathrm{C}_{6} \mathrm{D}_{6}\right): 7.18(\mathrm{~m}, 2 \mathrm{H}$, pyrrolyl $\mathrm{CH}), 6.56(\mathrm{~m}$, $2 \mathrm{H}$, pyrrolyl $\mathrm{CH}), 6.32(\mathrm{~m}, 2 \mathrm{H}$, pyrrolyl $\mathrm{CH}), 3.48(\mathrm{~m}$, $12 \mathrm{H}, \mathrm{NCH}_{2} \mathrm{CH}_{3}$ and $\left.\mathrm{CH}_{2} \mathrm{NMe}_{2}\right), 2.02(\mathrm{~s}, 12 \mathrm{H}$, $\mathrm{CH}_{2} \mathrm{NMe}$ ), 0.84 (t, $\left.12 \mathrm{H}, \mathrm{NCH}_{2} \mathrm{CH}_{3}\right) .{ }^{13} \mathrm{C} \mathrm{NMR}$ $\left(\mathrm{C}_{6} \mathrm{D}_{6}\right): 136.0$ (s, pyrrolyl $\left.C_{\mathrm{ipso}}\right), 128.5\left(\mathrm{~d}, J_{\mathrm{CH}}=178\right.$ $\mathrm{Hz}$, pyrrolyl $C \mathrm{H}), 109.4\left(\mathrm{~d}, J_{\mathrm{CH}}=165 \mathrm{~Hz}\right.$, pyrrolyl $C \mathrm{H}), 104.9\left(\mathrm{~d}, J_{\mathrm{CH}}=164 \mathrm{~Hz}\right.$, pyrrolyl $\left.C \mathrm{H}\right), 63.0(\mathrm{t}$, $\left.J_{\mathrm{CH}}=137 \mathrm{~Hz}, C \mathrm{CH}_{2} \mathrm{NMe}_{2}\right), 48.4\left(\mathrm{q}, J_{\mathrm{CH}}=136 \mathrm{~Hz}\right.$, $\left.\mathrm{N} M e_{2}\right), 40.8\left(\mathrm{t}, J_{\mathrm{CH}}=131 \mathrm{~Hz}, \mathrm{NCH}_{2} \mathrm{CH}_{3}\right), 13.0$ (q, $J_{\mathrm{CH}}=125 \mathrm{~Hz}, \quad \mathrm{NCH}_{2} \mathrm{CH}_{3}$ ). Anal. Calc. for $\mathrm{C}_{22} \mathrm{H}_{42} \mathrm{~N}_{6} \mathrm{Hf}: \mathrm{C}, 46.43 ; \mathrm{H}, 7.44 ; \mathrm{N}, 14.77$. Found: C, 45.60; H, 7.79; N, 15.23\%.

\section{3. $\left[\mathrm{C}_{4} \mathrm{H}_{3} \mathrm{~N}\left(\mathrm{CH}_{2} \mathrm{NMe}_{2}\right)-2\right]_{2} \mathrm{Hf}\left[\mathrm{PhNC}\left(\mathrm{NEt}_{2}\right) \mathrm{O}_{2}\right.$ (2)}

To a $50 \mathrm{~mL}$ Schlenk flask charged with $20 \mathrm{~mL}$ diethyl ether and $\mathbf{1}$ (2.0 g, $3.5 \mathrm{mmol})$ was added $\mathrm{PhNCO}(0.84 \mathrm{~g}$, $7.1 \mathrm{mmol}$ ) via syringe at room temperature. The solution color changed from pale yellow to dark red. Volatiles were removed under vacuum after 30 min stirring and the resulting solids were recrystallized from a diethyl ether solution to generate $1.59 \mathrm{~g}$ of white solids in $56 \%$ yield. ${ }^{1} \mathrm{H}$ NMR $\left(\mathrm{C}_{6} \mathrm{D}_{6}\right): 7.67(\mathrm{~m}, 2 \mathrm{H}$, phenyl
$\mathrm{CH})$, 7.27-6.95 (m, 10H, phenyl and pyrrolyl $\mathrm{CH}$ ), $6.59(\mathrm{~m}, 2 \mathrm{H}$, pyrrolyl $\mathrm{CH}), 6.45(\mathrm{~m}, 2 \mathrm{H}$, pyrrolyl $\mathrm{CH})$, $4.09\left(\mathrm{~d}, \quad J_{\mathrm{HH}}=13.2 \mathrm{~Hz}, \quad \mathrm{CH}_{a} \mathrm{H}_{b} \mathrm{NMe}_{2}\right), 3.14(\mathrm{~d}$, $\left.J_{\mathrm{HH}}=13.2 \mathrm{~Hz}, \mathrm{CH}_{a \mathrm{H} b} \mathrm{NMe}_{2}\right), 2.78\left(\mathrm{br}, 8 \mathrm{H}, \mathrm{NCH}_{2} \mathrm{CH}_{3}\right.$ ), 2.18 (br, $12 \mathrm{H}, \mathrm{CH}_{2} \mathrm{NMe}$ ), 0.79 (br, $6 \mathrm{H}, \mathrm{NCH}_{2} \mathrm{CH}_{3}$ ), 0.60 (br, $\left.6 \mathrm{H}, \mathrm{NCH}_{2} \mathrm{CH}_{3}\right) .{ }^{13} \mathrm{C} \mathrm{NMR}\left(\mathrm{C}_{6} \mathrm{D}_{6}\right): 165.9$ (s, $\mathrm{NCO}$ ), 146.4 (s, phenyl $C_{\mathrm{ipso}}$ ), 136.3 (s, pyrrolyl $C_{\mathrm{ipso}}$ ), $129.9\left(\mathrm{~d}, J_{\mathrm{CH}}=181 \mathrm{~Hz}\right.$, pyrrolyl $\left.C \mathrm{H}\right), 128.2(\mathrm{~d}$, $J_{\mathrm{CH}}=158 \mathrm{~Hz}$, phenyl $\left.C \mathrm{H}\right), 127.9,122.9\left(\mathrm{~d}, J_{\mathrm{CH}}=160\right.$ $\mathrm{Hz}$, phenyl $C \mathrm{H}), 107.0\left(\mathrm{~d}, J_{\mathrm{CH}}=163 \mathrm{~Hz}\right.$, pyrrolyl $C \mathrm{H}), 104.9\left(\mathrm{~d}, J_{\mathrm{CH}}=156 \mathrm{~Hz}\right.$, pyrrolyl $\left.C \mathrm{H}\right), 61.2(\mathrm{t}$, $\left.J_{\mathrm{CH}}=134 \mathrm{~Hz}, C \mathrm{H}_{2} \mathrm{NMe}_{2}\right), 49.5\left(\mathrm{q}, J_{\mathrm{CH}}=137 \mathrm{~Hz}\right.$, $\left.\mathrm{NMe} e_{2}\right), 41.2\left(\mathrm{t}, J_{\mathrm{CH}}=137 \mathrm{~Hz}, \mathrm{NCH}_{2} \mathrm{CH}_{3}\right), 13.2$ (q, $\left.J_{\mathrm{CH}}=126 \mathrm{~Hz}, \quad \mathrm{NCH}_{2} \mathrm{CH}_{3}\right)$. Anal. Calc. for $\mathrm{C}_{36} \mathrm{H}_{52} \mathrm{~N}_{8} \mathrm{O}_{2} \mathrm{Hf}$ : C, 53.56; H, 6.49; N, 13.88. Found: C, $52.73 ; \mathrm{H}, 5.93 ; \mathrm{N}, 13.99 \%$.

\section{4. $\left[\mathrm{C}_{4} \mathrm{H}_{3} \mathrm{~N}\left(\mathrm{CH}_{2} \mathrm{NMe}_{2}\right)-2\right] \mathrm{Hf}\left[\mathrm{PhNC}\left(\mathrm{NEt}_{2}\right) \mathrm{O}_{3}(\mathbf{3})\right.$}

Similar procedure as for $\mathbf{2}$ has been used here. 1 (2.0 $\mathrm{g}, 3.5 \mathrm{mmol})$ and $\mathrm{PhNCO}(0.84 \mathrm{~g}, 7.1 \mathrm{mmol})$ were used and stirred for 6 days. Repeating recrystallization of resulting mixture from a diethyl ether solution yields $0.40 \mathrm{~g}$ of 3 in $14 \%$ yield. Small amount of 2 was found in the final product. ${ }^{1} \mathrm{H}$ NMR $\left(\mathrm{C}_{6} \mathrm{D}_{6}\right): 7.58(\mathrm{~m}, 1 \mathrm{H}$, phenyl $\mathrm{CH}$ ), 6.90-7.38 (br, $15 \mathrm{H}$, phenyl + pyrrolyl $\mathrm{CH}$ ), $6.67(\mathrm{~m}, 1 \mathrm{H}$, pyrrolyl $\mathrm{CH}), 6.54(\mathrm{~m}, 1 \mathrm{H}$, pyrrolyl $\mathrm{CH})$, $4.01\left(\mathrm{~m}, 2 \mathrm{H}, \mathrm{CH}_{2} \mathrm{NMe}_{2}\right), 2.65-2.73$ (br, $15 \mathrm{H}, \mathrm{N}$ $\mathrm{CH}_{2} \mathrm{Me}+\mathrm{NMe}$ ), 2.27 (br, 3H, $\mathrm{NMe}$ ), 0.73 (br, $18 \mathrm{H}$, $\left.\mathrm{NCH}_{2} \mathrm{Me}\right) .{ }^{13} \mathrm{C}$ NMR $\left(\mathrm{C}_{6} \mathrm{D}_{6}\right): 167.0(\mathrm{~s}, \mathrm{NCO}), 166.2$ (s, NCO), 146.7 (s, br, phenyl, $\mathrm{C}_{\mathrm{ipso}}$ ), 135.6 (s, pyrrolyl, $\left.\mathrm{C}_{\mathrm{ipso}}\right), 128.8\left(\mathrm{~d}, J_{\mathrm{CH}}=183 \mathrm{~Hz}\right.$, pyrrolyl $\left.C \mathrm{H}\right), 128.3(\mathrm{~d}$, $J_{\mathrm{CH}}=159 \mathrm{~Hz}$, phenyl $\left.C \mathrm{H}\right), 124.7\left(\mathrm{~d}, J_{\mathrm{CH}}=156 \mathrm{~Hz}\right.$, phenyl $C H$,), $124.3\left(\mathrm{~d}, J_{\mathrm{CH}}=156 \mathrm{~Hz}\right.$, phenyl $\left.C \mathrm{H}\right), 122.2(\mathrm{~d}$, $J_{\mathrm{CH}}=162 \mathrm{~Hz}$, phenyl $\left.C \mathrm{H}\right), 106.4\left(\mathrm{~d}, J_{\mathrm{CH}}=174 \mathrm{~Hz}\right.$, pyrrolyl $C \mathrm{H}$,), $103.0\left(\mathrm{~d}, J_{\mathrm{CH}}=163 \mathrm{~Hz}\right.$, pyrrolyl $\left.C \mathrm{H}\right), 62.5$ and 62.6 (two t, $J_{\mathrm{CH}}=139 \mathrm{~Hz}, C \mathrm{H}_{2} \mathrm{NMe}_{2}$ ), 48.6 (q, $\left.J_{\mathrm{CH}}=140 \mathrm{~Hz}, \mathrm{NMe}\right), 41.4\left(\mathrm{t}, J_{\mathrm{CH}}=134 \mathrm{~Hz}, \mathrm{NCH}_{2} \mathrm{Me}\right)$, $37.2\left(\mathrm{q}, J_{\mathrm{CH}}=138 \mathrm{~Hz}, \mathrm{NMe}\right), 13.4\left(\mathrm{q}, J_{\mathrm{CH}}=128 \mathrm{~Hz}\right.$, $\mathrm{NCH}_{2} \mathrm{Me}$ ). No elemental analysis was performed due to small amount of compound $\mathbf{2}$ was presented.

\section{5. $\mathrm{Hf}\left[\mathrm{PhNC}\left(\mathrm{NEt}_{2}\right) \mathrm{O}_{4}(4)\right.$}

To a $50 \mathrm{~mL}$ Schlenk flask charged with $20 \mathrm{~mL}$ toluene and $\mathrm{Hf}\left(\mathrm{NEt}_{2}\right)_{4}(1.0 \mathrm{~g}, 2.14 \mathrm{mmol})$ was added $\mathrm{PhNCO}$ $(1.02 \mathrm{~g}, 8.56 \mathrm{mmol})$ via syringe at room temperature. The color remained pale yellow after $1 \mathrm{~h}$ of stirring. Volatiles were removed under vacuum and the resulting solids were recrystallized from a toluene solution at $-20^{\circ} \mathrm{C}$ to generate $1.78 \mathrm{~g}$ of white solids in $88 \%$ yield. ${ }^{1} \mathrm{H}$ NMR $\left(\mathrm{C}_{6} \mathrm{D}_{6}\right)$ : 7.35-6.95 (m, 20H, phenyl $\left.\mathrm{CH}\right), 2.89$ (q, 16H, $\left.\mathrm{NCH}_{2} \mathrm{CH}_{3}\right), 0.71\left(\mathrm{t}, 24 \mathrm{H}, \mathrm{NCH}_{2} \mathrm{CH}_{3}\right) .{ }^{13} \mathrm{C} \mathrm{NMR}$ $\left(\mathrm{C}_{6} \mathrm{D}_{6}\right): 166.6$ (s, NCO), 147.9 (s, phenyl $C_{\mathrm{ipso}}$ ), 128.2 $\left(\mathrm{d}, J_{\mathrm{CH}}=156 \mathrm{~Hz}\right.$, phenyl $\left.C \mathrm{H}\right), 124.5\left(\mathrm{~d}, J_{\mathrm{CH}}=159\right.$ $\mathrm{Hz}$, phenyl $C \mathrm{H}), 121.6\left(\mathrm{~d}, J_{\mathrm{CH}}=159 \mathrm{~Hz}\right.$, phenyl $\left.C \mathrm{H}\right)$, 
Table 2

Crystallographic data and refinement for compounds 1, 2, 3 and 4

\begin{tabular}{|c|c|c|c|c|}
\hline & 1 & 2 & 3 & 4 \\
\hline Formula & $\mathrm{C}_{22} \mathrm{H}_{42} \mathrm{HfN}_{6}$ & $\mathrm{C}_{36} \mathrm{H}_{52} \mathrm{HfN}_{8} \mathrm{O}_{2}$ & $\mathrm{C}_{40} \mathrm{H}_{56} \mathrm{HfN}_{8} \mathrm{O}_{3}$ & $\mathrm{C}_{44} \mathrm{H}_{60} \mathrm{HfN}_{8} \mathrm{O}_{4}$ \\
\hline$F_{\mathrm{w}}$ & 569.11 & 807.35 & 875.42 & 943.49 \\
\hline Temperature (K) & $293(2)$ & $150(2)$ & $150(1)$ & $150(2)$ \\
\hline Crystal system & Monoclinic & Monoclinic & Monoclinic & Monoclinic \\
\hline Space group & $P 2_{1} / c$ & $P 2_{1} / c$ & $P 2_{1} / c$ & $C c$ \\
\hline$a(\AA)$ & $10.022(3)$ & $15.548(4)$ & $11.1338(1)$ & $11.4627(15)$ \\
\hline$b(\AA)$ & $16.370(4)$ & $10.867(3)$ & $23.5981(3)$ & $16.219(2)$ \\
\hline$c(\AA)$ & $15.515(4)$ & $21.237(5)$ & $15.1340(2)$ & $23.993(3)$ \\
\hline$\beta\left({ }^{\circ}\right)$ & $104.020(4)$ & $94.427(4)$ & $105.8891(5)$ & $100.622(2)$ \\
\hline$V\left(\AA^{3}\right)$ & $2469.4(11)$ & $3577.5(14)$ & $3824.33(8)$ & $4384.1(10)$ \\
\hline$Z$ & 4 & 4 & 4 & 4 \\
\hline$D_{\text {calc }}\left(\mathrm{g} / \mathrm{cm}^{3}\right)$ & 1.531 & 1.499 & 1.520 & 1.429 \\
\hline$F(000)$ & 1152 & 1648 & 1792 & 1936 \\
\hline$\theta$ Range $\left(^{\circ}\right)$ & $1.84-27.58$ & $1.31-27.55$ & $1.64-25.00$ & $1.73-27.53$ \\
\hline No. of reflections collected & 15560 & 24310 & 30498 & 21771 \\
\hline No. of independent reflections $\left(R_{\text {int }}\right)$ & $5657(0.0374)$ & $8142(0.1254)$ & $6728(0.0619)$ & $9677(0.0317)$ \\
\hline No. of parameters & 270 & 424 & 469 & 514 \\
\hline Goodness of fit on $F^{2-}$ & 0.848 & 0.898 & 1.127 & 0.921 \\
\hline Final $R, w R_{2}[I>2 \sigma(I)]$ & $0.0221,0.0388$ & $0.0606,0.1582$ & $0.0543,0.1414$ & $0.0263,0.0544$ \\
\hline$R, w R_{2}$ (all data) & $0.0338,0.0401$ & $0.1205,0.1834$ & $0.0856,0.1691$ & $0.0307,0.0544$ \\
\hline$\Delta \rho_{\max , \min }\left(\mathrm{e} \AA^{-3}\right)$ & $0.884,-1.271$ & $2.847,-2.502$ & $1.984,-1.263$ & $1.392,-0.398$ \\
\hline
\end{tabular}

$41.4\left(\mathrm{t}, J_{\mathrm{CH}}=137 \mathrm{~Hz}, \mathrm{NCH}_{2} \mathrm{CH}_{3}\right), 13.4\left(\mathrm{q}, J_{\mathrm{CH}}=126\right.$ $\left.\mathrm{Hz}, \mathrm{NCH}_{2} \mathrm{CH}_{3}\right)$. Anal. Calc. for $\mathrm{C}_{44} \mathrm{H}_{60} \mathrm{~N}_{8} \mathrm{O}_{4} \mathrm{Hf}$ : C, $56.01 ; \mathrm{H}, 6.41 ; \mathrm{N}, 11.88$. Found: $\mathrm{C}, 56.03 ; \mathrm{H}, 6.07 ; \mathrm{N}$, 12.01 .

\section{X-ray structure determination of compounds $1,2,3$ and 4}

The crystals 1, 2, and 4 were mounted in glass fibers under nitrogen and transferred to a goniostat. Data were collected on a Bruker SMART CCD diffractometer with graphite-monochromated Mo $\mathrm{K} \alpha$ radiation with the radiation wavelength of $0.71073 \AA$. Data for crystal 3 were collected on a Nonius KappaCCD diffractometer. A SADABS absorption correction was made. All refinements were carried out by full-matrix least squares using anisotropic displacement parameters for all non-hydrogen atoms. All the hydrogen atoms are calculated. The crystal data are summarized in Table 2.

\section{Acknowledgement}

We thank the National Science Council of Taiwan for the financial support and the National High Performance Computing Center of Taiwan for supporting databank searching.

\section{Appendix A. Supplementary material}

Crystallographic data for the structural analysis have been deposited with the Cambridge Crystallographic
Data Centre, CCDC nos. 234583-234585 and 243419. Copies of this information may be obtained free of charge from The Director, CCDC, 12 Union Road, Cambridge CB2 1 EZ, UK (fax: +44-1223-336033; e-mail: deposit@ccdc.cam.ac.uk or http://www.ccdc.cam.ac.uk). Data for theoretical calculation can be obtained from the author by request via e-mail at juihuang@cc.ncue.edu.tw. Supplementary data associated with this article can be found, in the online version, at doi:10.1016/j.jorganchem.2004.07.046.

\section{References}

[1] H. Ulrich, Acc. Chem. Res. 2 (1969) 186.

[2] J.H. Saunder, K.C. Frisch, Polyurethanes, Wiely-Interscience, New York, 1962.

[3] F. L'Eplattenier, P. Matthys, F. Calderazzo, Inorg. Chem. 9 (1970) 342

[4] A.F.M. Iqbal, J. Org. Chem. 37 (1972) 2791.

[5] J.A. Smieja, J.E. Gozum, W.L. Gladfelter, Organometallics 6 (1987) 1311.

[6] G.D. Williams, R.R. Whittle, G.L. Geoffroy, A.L. Rheingold, J. Am. Chem. Soc. 109 (1987) 3936.

[7] S.R. Foley, Y. Zhou, G.P.A. Yap, D.S. Richeson, Inorg. Chem. 39 (2000) 924.

[8] P. Braunstein, D. Nobel, Chem. Rev. 89 (1989) 1927.

[9] P. Legzdins, S.J. Rettig, K.J. Ross, Organometallics 13 (1994) 569.

[10] B. Srinivas, C.C. Chang, C.H. Chen, M.Y. Chiang, I.T. Chen, Y. Wang, G.H. Lee, J. Chem. Soc., Dalton Trans. (1997) 957.

[11] R.L. Cowan, W.C. Trogler, J. Am. Chem. Soc. 111 (1989) 4750.

[12] K. Weiss, U. Schubert, R.R. Schrock, Organometallics 5 (1986) 397.

[13] W.J. Evans, K.J. Forrestal, J.W. Ziller, J. Am. Chem. Soc. 120 (1998) 9273.

[14] Q. Shen, H. Li, C. Yao, Y. Yao, L. Zhang, K. Yu, Organometallics 20 (2001) 3070 . 
[15] X.G. Zhou, L.B. Zhang, M. Zhu, R.F. Cai, L.H. Weng, Z.X. Huang, Q.J. Wu, Organometallics 20 (2001) 5700.

[16] W.J. Evans, R.N.R. Broomhall-Dillard, J.W. Ziller, J. Organomet. Chem. 569 (1998) 89.

[17] L. Mao, Q. Shen, M. Xue, J. Sun, Organometallics 16 (1997) 3711.

[18] J.L. Thorman, I.A. Guzei, V.G. Young Jr., L.K. Woo, Inorg. Chem. 38 (1999) 3814.

[19] S. Gambarotta, S. Strologo, C. Floriani, A. Chiesi-Villa, C. Guastini, Inorg. Chem. 24 (1985) 654.

[20] G. Chandra, A.D. Jenkins, M.F. Lappert, R.C. Srivastava, J. Chem. Soc. A (1970) 2550

[21] A reaction product of $\mathrm{PhNCO}$ with 2-(diemthylaminomethylpyrrole) see: C.F. Chia, H.J. Chen, J.C. Chang, C.H. Hung, C.C. Lai, C.H. Hu, J.H. Huang, Inorg. Chem. 43 (2004) 2183.

[22] M.H. Chisholm, C.E. Hammond, D. Ho, J.C. Huffman, J. Am. Chem. Soc. 108 (1986) 7860

[23] A.D.J. Becke, J. Chem. Phys. 98 (1993) 5648.
[24] C. Lee, W. Yang, R.G. Parr, Phys. Rev. B 37 (1988) 785.

[25] P.J. Hay, W.R. Wadt, J. Chem. Phys. 82 (1985) 270.

[26] M.J. Frisch, G.W. Trucks, H.B. Schlegel, G.E. Scuseria, M.A. Robb, J.R. Cheeseman, V.G. Zakrzewski, J.A. Montgomery Jr., R.E. Stratmann, J.C. Burant, S. Dapprich, J.M. Millam, A.D. Daniels, K.N. Kudin, M.C. Strain, O. Farkas, J. Tomasi, V. Barone, M. Cossi, R. Cammi, B. Mennucci, C. Pomelli, C. Adamo, S. Clifford, J. Ochterski, G.A. Petersson, P.Y. Ayala, Q. Cui, K. Morokuma, D.K. Malick, A.D. Rabuck, K. Raghavachari, J.B. Foresman, J. Cioslowski, J.V. Ortiz, B.B. Stefanov, G. Liu, A. Liashenko, P. Piskorz, I. Komaromi, R. Gomperts, R.L. Martin, D.J. Fox, T. Keith, M.A. Al-Laham, C.Y. Peng, A. Nanayakkara, C. Gonzalez, M. Challacombe, P.M.W. Gill, B. Johnson, W. Chen, M.W. Wong, J.L. Andres, C. Gonzalez, M. Head-Gordon, E.S. Replogle, J.A. Pople, Revision A.12 ed., Gaussian Inc., Pittsburgh PA, 2001.

[27] W. Herz, K. Dittmer, J. Am. Chem. Soc. 69 (1947) 1698.

[28] I.T. Kim, R.L. Elsenbaumer, Tetrahedron Lett. 39 (1998) 1087. 